\title{
ІНСТИТУЦІЙНІ ЗАСАДИ ФУНКЦІОНУВАННЯ ФІНАНСОВОГО РИНКУ В УМОВАХ ЦИФРОВІЗАЦІЇ СУСПІЛЬСТВА
}

\author{
Кравченко Анна Станіславівна \\ кандидат економічних наук, доцент \\ ДВН3 «Університет банківської справи» (м. Львів, Україна) \\ ORCID: 0000-0003-1977-8181 \\ vovchak.olga@meta.ua
}

Досліджено інституційні засади функціонування фінансового ринку в умовах цифрровізаиії суспільства, зокрема проаналізовано поняття «інститут», «інституція», види інституиій, уточнено дефрініцію «фінансовий інститут», побудовано інституційну модель фрункціонування фрінансового ринку в цифрових умовах

Ключові слова: інститут, інституція, види інституцій, фінансовий інститут, інституційна модель функціонування фонансового ринку в цифррових умовах

DOI: https://doi.org/10.32845/bsnau.2019.3.2

Постановка проблеми. Інституції сучасного фінансового ринку розвиваються в умовах цифрровізації суспільства. Електронізація набуває динамічного розвитку в глобальному економічному середовищі. В свою чергу, інституції фінансової системи, потребують цифрової трансформації. Для забезпечення належного функціонування фінансового ринку під впливом глобальних тенденцій сьогодення, постає гостра необхідність проведення удосконалення його інституційної складової за функціональним призначенням, що забезпечить стійкість, дієздатність фінансової системи і сталий розвиток країни.

Аналіз основних досліджень та публікацій. Вивченню питань фінансових інституцій та деякі з них цифровізацією, займались: Н. Негропонте, М.Лівінгстон, $Є$. Біргхем, Г. Журавльова, В. Нордхаус, В. Суторміна, В. Базилевич, Ж. Гарбар тощо, проте незважаючи на існуючу кількість публікацій за науковою тематикою, питання інституційних засад функціонування фінансового ринку в умовах цифровізації суспільства не достатньо досліджені та потребують подальшого розвитку.

Постановка завдання. Мета дослідження - дослі-

дити та побудувати модель інституційних засад функціонування фінансового ринку в умовах цифровізації суспільства. Методика (методологія) дослідження - для уточнення та побудови інституційної моделі функціонування фінансового ринку в цифрових умовах, застосовано комплексний, системний, синергетичний, кібернетичний підходи та методи групування, аналізу, синтезу, моделювання, абстрактно-логічний.

Виклад основного матеріалу. Архітектоніка сучасного фінансового ринку є множинною, багаторівневою системою національних та міжнародних фінансових інституцій, державної і приватної форми власності із чисельними взаємозв'язками. Система дослідження інституційних засад функціонування фінансового ринку, складається з елементів: уточнення дефініцій «інститут», «інституція», види інститутів, 30крема фінансових, визначення поняття «функціональне призначення», «інституційна сегментація фінансового ринку за функціональним призначенням», побудова моделі удосконаленої інституційної сегментації фінансового ринку за функціональним призначенням.

Дефініція «інститут», розкривається з різних наукових поглядів (таб.1).

Таблиця 1

Аналіз дефініції «інститут»

\begin{tabular}{|l|l|l|}
\hline \multicolumn{1}{|c|}{ Вчений } & \multicolumn{1}{|c|}{ Сутність десрініції «інститут» } & \multicolumn{1}{|c|}{ Науковий підхід } \\
\hline $\begin{array}{l}\text { М. Кармазіна, } \\
\text { О. Шурбована }\end{array}$ & $\begin{array}{l}\text { Організація, з відповідними правилами, які стверджуються в процесі } \\
\text { взаємодії практичних та встановлених норм [2, с. 10-19] }\end{array}$ & Інституційно-нормативний \\
\hline С. Матвєєв, Л. Лясота & Організації, норми, правила гри [1] & Снституційно-нормативний \\
\hline Г. Спенсер & Суспільна підсистема регулювання[2, с. 10-19] & Інструментальний \\
\hline Т. Парсонс & Адаптаційно-інтеграційний інструмент [1] & Соціальний \\
\hline М. Вебер, К. Маркс & Соціальна інженерія [2, с. 10-19] & 3мішаний \\
\hline О. Стрижак & Дії, норми, структурні організації, регулятор витрат, традиції [3, с. 40] & Нормативний \\
\hline М. Оріу & Норма об'єктивного права [2, с. 10-19] & Інституційно-еволюційний \\
\hline О. Іншаков & Комплекси інституцій, гентотип організацій еволюційної моделі [3, с. 39] & Нормативний \\
\hline К. Касторіадіс & Правові зв'язки [2, с. 10-19] & Соціальний \\
\hline М. Дюверже & Соціально-впорядкована цілісність [2, с. 10-19] & Функціональний \\
\hline Дж. Коммонс & Контролююча функція індивідуальних дій [3, с.39] & Інституцйно-функціональний \\
\hline В. Дементьєв & Суспільний механізм, щодо функціонування сталої організації [3, с. 39] & Інституційний \\
\hline Д. Норт & Різні державні та приватні організації [2, с. 10-19] & Нормативний \\
\hline Г. Шмоллєр & Набір правил, засобів їх забезпечення [3, с. 39] & \\
\hline
\end{tabular}

*Джерело: власне дослідження

Дослідження зазначеного поняття, виявили відсутність та необхідність застосування комплексного підходу, із застосуванням якого уточнена дефініція «інститут» - це система нормативно-правових взаємовідносин сформованих ор- ганізованих об'єднань, як детермінанти функціонуючого суспільного буття.

В свою чергу, дефініція «інституція», розкривається переважно з суспільного погляду (табл.2). 
Таблиця 2

Аналіз дефініції «інституція»

\begin{tabular}{l|l|l|}
\hline \multicolumn{1}{|c|}{ Вчений } & \multicolumn{1}{|c|}{ Сутність десрініції «інституція» } & \multicolumn{1}{|c|}{ Науковий підхід } \\
\hline $\begin{array}{l}\text { М. Кармазіна, } \\
\text { О. Шурбована }\end{array}$ & $\begin{array}{l}\text { Порядок, традиції суспільства; семіотичні, звичаєві значення, практики } \\
\text { відтворені інститутами [2, с. 10-19] }\end{array}$ & Змішаний \\
\hline С. Матвєєв, Л. Лясота & Правила, щодо функціонування соціально-економічного простору [1] & Нормативно-фрункціональний \\
\hline П. Рікер & Воля, почуття группи людей в історичний момент & Соціально-історичний \\
\hline О. Стрижак & Порядок, що прийнятий у суспільстві [3, с. 40] & Нормативно-суспільний \\
\hline Д. Норт & $\begin{array}{l}\text { Механізми, правила, закони, звичаї, норми поведінки взаємодії людей у } \\
\text { суспільстві [1], [2, с. 10-19] }\end{array}$ & Нормативно-суспільний \\
\hline О. Шпикуляк & Правила, традиції, стереотипи [3, с. 40] & Нормативно-соціальний \\
\hline В. Гриценко & Діяльність певних груп у суспільстві [3, с. 40] & Суспільний \\
\hline
\end{tabular}
*Джерело: власне дослідження

Отже, уточнена десініція «інституція» - це система норм, усталених поглядів суспільства, що забезпечується організаційним відтворенням.

Таблиця 3

Дослідження видів інститутів

\begin{tabular}{|l|l|l|l|l|}
\hline \multicolumn{1}{|c|}{ Види інститутів/автори } & Г. Дворецька, Е. Гофман & \multicolumn{1}{|c|}{ Л.Радіонова } & О. Бердюгіна, В. Глазирін, А. Грібакін & Жарбар \\
\hline Економічні & + & + & + & + \\
\hline Політичні & + & + & + & + \\
\hline Релігійні & + & + & & + \\
\hline Культурно-соціальні, або культ.дух. & + & & + & \\
\hline Соціалізації & & + & & \\
\hline Освітіні & & + & & \\
\hline Сімейно-шлюбні, або сім'ї & & & & + \\
\hline Тотальні & + & & \\
\hline
\end{tabular}

`Джерело: власне дослідження

Дослідження видів інститутів показало (табл.3), необхідність виділення всіх сфер суспільного життя, проте вчені не в повному обсязі розкрили їх. Отже, інститути, варто поділяти на такі сфрери суспільного буття, як: економічно-фінансову; соціально-політичну; соціально-родинну; освітньо-наукову; культурно-релігійну; пенітенціарну; кібернетичну.
Тлумачення дефініції «фрінансовий інститут», розкрито авторами з використання різних прийомів для розкриття сутності поняття, проте цілісно-системний науковий підхід в дослідженнях не прослідковується (табл.4).

Аналіз дефрініції «фрінансовий інститут»

\begin{tabular}{|c|c|c|}
\hline Вчений & $\begin{array}{c}\text { Сутність десініції } \\
\text { «фінансовий інститут» }\end{array}$ & Науковий підхід \\
\hline М.Лівінгстон, Є. Біргхем & $\begin{array}{l}\text { Організації, які спрямовують фінансові потоки із секторів з вільними } \\
\text { грошовими коштами до секторів з їх дефріцитом [4] }\end{array}$ & Інституційно-функціональний \\
\hline Г. Журавльова, В. Відяпін & $\begin{array}{l}\text { Інститути, які надають фондові, кредитні, посередницькі послуги та } \\
\text { організовують платіжний обіг [4] }\end{array}$ & Інституційно-функціональний \\
\hline $\begin{array}{l}\text { О. Бондаренко, } \\
\text { І. Адаменко }\end{array}$ & $\begin{array}{l}\text { Організації, що забезпечують дотримання норм фінансового ринку, } \\
\text { опосередковують взаємодію його агентів та формують механізм ринкової } \\
\text { координації [107, с. 8-11] }\end{array}$ & $\begin{array}{c}\text { Нормативний, } \\
\text { інституційно-ффункціональний }\end{array}$ \\
\hline В. Нордхаус & $\begin{array}{l}\text { Організації, які переводять грошові фонди від позичальників до } \\
\text { кредиторів [4] }\end{array}$ & Інституційно-функціональний \\
\hline В. Базилевич & $\begin{array}{l}\text { Організації, щодо опосередковання та впорядкування взаємодії агентів } \\
\text { фондового ринку [106] }\end{array}$ & Інституційно-функціональний \\
\hline В. Суторміна & $\begin{array}{l}\text { Інстиути, що перетворюють прямі вимоги в посередницькі, через } \\
\text { придбання первинних цінних паперів, а також випуску власних [4] }\end{array}$ & Інституційно-функціональний \\
\hline О. Стойко, Д. Дема & Посередники, що проводять зустрічі учасників фрінансового ринку [5] & Функціональний \\
\hline Ж. Гарбар & $\begin{array}{l}\text { Організації, що акумулюють вільні фінансові ресурси та здійснюють } \\
\text { нормативне регулювання доступу економічних агентів на основі попиту- } \\
\text { пропозиції [4] }\end{array}$ & $\begin{array}{c}\text { Нормативний, } \\
\text { інституційно-функкціональний }\end{array}$ \\
\hline
\end{tabular}

*Джерело: власне дослідження 


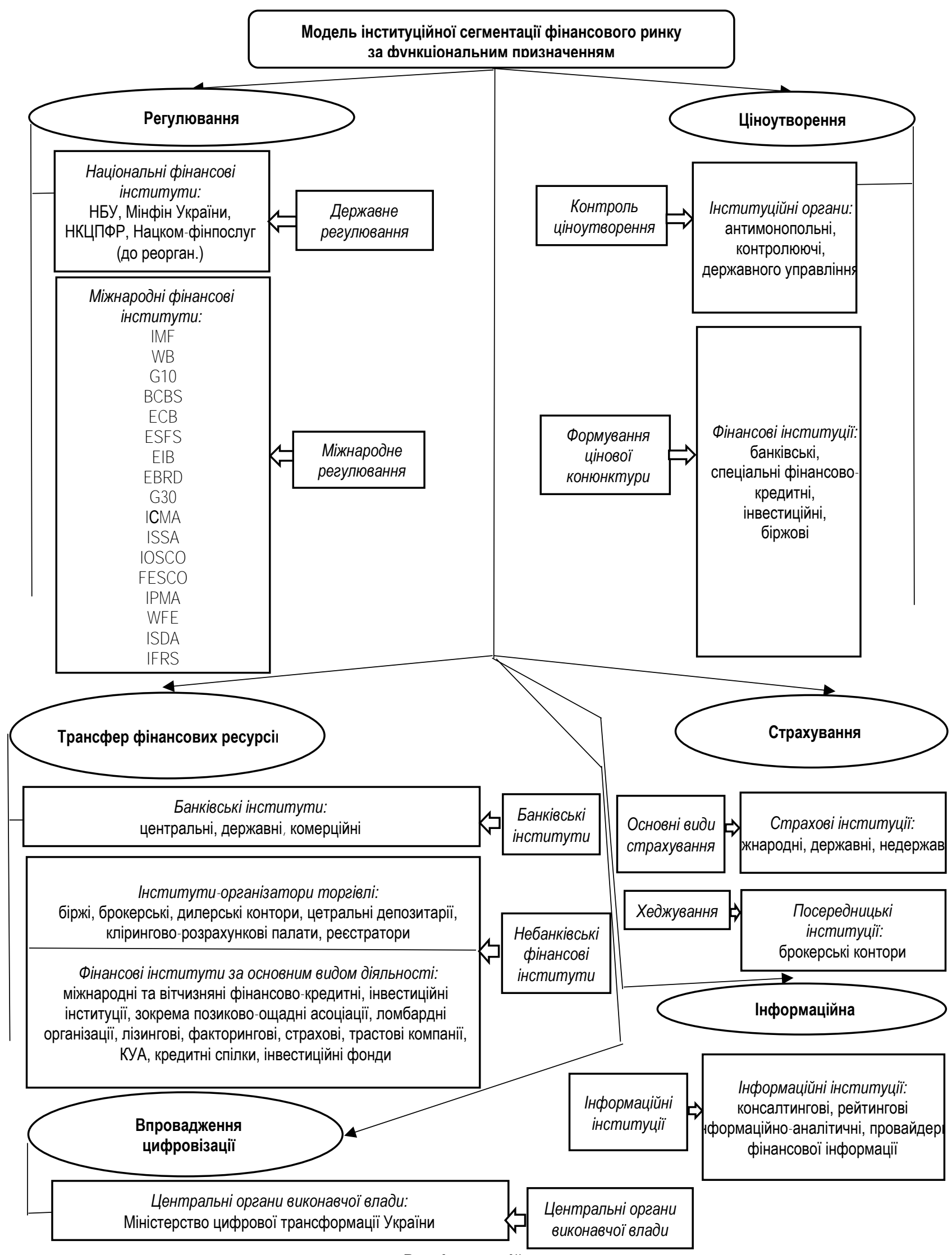

Джерело: власне дослідження

Рис. Інституційна модель 
Уточнено, що фінансовий інститут - це організаційно сформовані в правовому полі установи, щодо здійснення ліцензованої фінансової діяльності, для забезпечення кумулятивного економічного ефекту на фінансовому ринку.

В свою чергу, в наукових публікаціях види фінансових інститутів розкриті фрагментарно, що потребує уточнення. Отже, модель удосконалена інституційної сегментації фінансового ринку представлена на (рис. 1).

Інституційна сегментація фінансового ринку за функ- ціональним призначенням - це комплексна, цілісна моделяційно-інституційна система, щодо визначення сегментації фрінансового ринку, залежно від його функціонального призначення.

Висновки. Фінансові інститути, здійснюють обслуговування ринкових суб'єктів, їх ефективізація сприятиме економічному розвитку. Використання моделі інституційної сегментації фінансового ринку за функціональним призначенням в умовах цифровізації суспільства сприятиме розбудові оптимізованої фінансової системи країни.

\section{Список використаної літератури:}

1.Матвєєв С.О. Економічна соціологія: підруч.// Матвєєв С.О., Лясота Л.І. - Суми: Університетська книга, 2006. - 184 с.

2.Кармазіна М. «Інститут» та «інституція»: проблема розрізнення понять // Проблеми методології. Політичний менеджмент/ М. Кармазіна, О. Шурбована.- 4.-2006.- С.10-19

3.Стрижак О. Поняття інституту: основні підходи до визначення суті та змісту//Економічна наука. Економіка та держава.8.-2016.- С. 38-43.

4.Гарбар Ж.В. Фінансовий ринок: монограф. / Ж.В. Гарбар. - К.: КНТЕУ, 2015. - 455 с.

5.Стойко О.Я. Фінанси: підруч. / О.Я. Стойко, Д.І. Дема; за ред. О.Я. Стойка. - К.: Алерта, 2017. - 406 с.

6.Фондовий ринок: підруч./за ред. В.Д. Базилевича. - К.: Знання, 2015. - 621с.

7.Бондаренко О.С. Перспективи розвитку фінансових інститутів в економіці України // Економічна наука. Інвестиції: практика та досвід / О.С. Бондаренко, І.П. Адаменко.- 5.-2018, С. 8-11. $-190 \mathrm{C}$.

8.Кравченко А.С. Функціонування біржового фінансового ринку: монограф./ А.С. Кравченко. - К. : ЦП «Компринт», 2015.

Kravchenko A.S., PhD, Associate Professor, Banking University Lviv Institute (Lviv, Ukraine)

Institutional fundamentals of financial market functioning in the circumstances of digitalization

Institutional bases of functioning of the financial market in the conditions of digitalization of society are investigated, in particular the concept of «institute», «institution», types of institutions are analyzed, the definition of «financial institute» is specified, the institutional model of functioning of the financial market in digital conditions is elaborated

Key words: institute, institution, types of institutions, financial institution, institutional model of functioning of the financial market in digital conditions

Дата надходження до редакції: 15.07.2019 р. 